\title{
Idiosyncratic Effect of Multi Antineoplastic Drug in Mammary Tumour of a Bitch: A Case Report
}

\author{
${ }^{1}$ Rekha Pathak
}

\begin{abstract}
The present study is a case report regarding treatment of mammary tumour in a German shepherd bitch where the tumour was attempted with antineoplastic drugs combination with Inj.Vincristine sulphate @ $0.0125 \mathrm{mg} / \mathrm{kg}$ body wt. intravenously at weekly interval, Tab. Methotrexoate $2.5 \mathrm{mg}$ once in a week.Tab Cyclophosphamide $50 \mathrm{mg}$ once in a week. There was a gap of at least 2-3 days between each above anticancerous drug. Unfortunately, the drugs had adverse effects on the hepato-renal status of the bitch however; it showed slight improvement in the size of the mammary tumour. The animal was immediately attended with symptomatic therapy and the side effects were controlled. The tumour was surgically removed; removal was easy as the size was shrinked. The results suggest that the therapeutic treatment of mammary tumour can be attempted with the same above drugs combination by probably reducing the dosages of individual drugs.
\end{abstract}

Key words: Mammary Tumour, Antineoplastic Drug, Vincrystine Sulfate, Methotrexoate, Cyclophosphamide.

\section{Introduction:}

Mammary gland tumors are among the commonest neoplasms in case of bitches. (Moulton 1999) and constitutes about $52 \%$ of all tumors found among them. (Brodey et al 1983).

Methotrexate is a folic acid analog used against a wide variety of neoplasm including lymphoreticular neoplasms, squamous cell carcinoma and canine transmissible venereal tumor. The toxicity reported is leucopenia, anemia, and thrombocytopenia, severe GI toxicity, stomatitis, anorexia, nausea and vomiting. Hepatotoxicity is seen by increase in SGPT, SGOT, and alkaline phosphatase. It also causes renal damage. Cylclophosphamide apart from the above symptoms causes sterile necrotizing hepatitis with bloody urine. Similarly, side effects of Vincristine are leucopenia and vomitions. (Booth and Mcdonald, 1982), and is true with all kinds of anticancerous drugs that they are associated with the side effects which are considerably important. (Sorenmo et al, 1993 and Hammer et al 1991).

A 6 years old German shepherd bitch weighing around $25 \mathrm{~kg}$ was reported to be having mammary tumor growths since past three months. It was also reported that the growth had considerably increased during this period of time. She was not taking food properly and was weak and exhausted after being walked. The reproduction history said that she was never mated during the heat periods. Biopsy sample was collected from the growth, fixed in formalin and processed routinely according to the standards of the histologic procedures and the finding was suggestive of neoplastic growth. Before initiating the combine anti-neoplastic drug therapy estimation of haemato biochemical parameters viz. $\mathrm{Hb}$, SGOT, BUN and creatinine were assessed. The parameters were found to be $9 \mathrm{gm} / \mathrm{dl}$, $80 \mathrm{IU} / \mathrm{lt}$., $12 \mathrm{mg} / \mathrm{dl}$ and $1 \mathrm{mg} / \mathrm{dl}$ respectively.

The multi anti-neoplastic drug therapy was adopted as a regimen in order to reduce the dose and toxicity of each drug and with the multi targeted approach to bring about a fast recovery (Shiv Kumar, 2000) due to synergistic effects of the drugs.

It was decided to first place her on medical treatment and which was to be followed by radical surgery if the size of growth was reduced.

Materials and Methods: Combined drug therapy with three drug regimes was followed.

Inj. Vincristine sulphate @ $0.0125 \mathrm{mg} / \mathrm{kg}$ body wt. intravenously at weekly interval, Tab. Methotrexoate $2.5 \mathrm{mg}$ once in a week and Tab Cyclophosphamide $50 \mathrm{mg}$ once in a week. There was a gap of at least 2-3 days between each above anticancerous drug.

Results: It was noticed that the size of the tumor started to shrink after a week but amazingly in the second week, the animal started showing the symptoms of severe gastrointestinal bleeding viz. hematemesis and melena. Apart from that she had severe hematuria followed by a complete anuria which was very serious and warranted an immediate attention. She was immediately given the medical concern and was examined for hemoglobin, SGOT , blood urea nitrogen and creatinine. The parameters were found to be $6 \mathrm{gm} / \mathrm{dl}, 800 \mathrm{IU}, 60$ $\mathrm{mg} / \mathrm{dl}$ and $10 \mathrm{mg} / \mathrm{dl}$. respectively which was alarming. She was given fluid therapy with Normal saline solution around one liter twice a day and Mannitol. To control bleeding Botropase $1 \mathrm{ml}$ intravenously was used. Inj. Neohepatex was also given to revive the damaged liver. Homeopathic preparation called Ipicac was given to 
control vomiting in the potency of $30 \mathrm{x}$ as 4 drops 4 times a day. Also inj. Metochlorpromide was given $2 \mathrm{ml}$ intravenously to control the vomitions. The antibiotic therapy with inj. Amoxicillin and Cloxacillin was also given. Inj. Levamisole was given s. c. @ $2.5 \mathrm{mg} / \mathrm{kg}$ body wt. as an immunomodulant. The frequency of retching (attempts to vomit) reduced from 30 / day to 15 times a day on the second day of treatment. Blood in stools was not seen after the $3^{\text {rd }}$ day of treatment and the animal started to urinate normally in frequency and volume. The haematological measurements viz. haemoglobin, SGOT, BUN and creatinine were respectively found to be around $8 \mathrm{gm} / \mathrm{dl}, 200 \mathrm{IU} / \mathrm{L}, 30 \mathrm{mg} / \mathrm{dl}$ and $4 \mathrm{mg} / \mathrm{dl}$ on the $3^{\text {rd }}$ day of the treatment. By the $7^{\text {th }}$ day animal showed a drastic recovery from the complications and survived. The haematological measurements viz. haemoglobin, SGOT, BUN and Creatinine were respectively found to be around $8 \mathrm{gm} / \mathrm{dl}, 70 \mathrm{IU}, 20 \mathrm{mg} / \mathrm{dl}$ and $2 \mathrm{mg} / \mathrm{dl}$ on the $7^{\text {th }}$ day of the treatment. The mammary tumor was removed surgically one month after the recovery of the animals under general anesthesia and the animal recovered uneventfully. Upto 6 months follow up there was absolutely no problem with the animal. It was feeding normally and showed a lot of improvement in its condition.

\section{Discussion:}

On the $4^{\text {th }}$ day due to the combined drug therapy there was a drastic reduction in the Hb concentration and increase in SGOT which was suggestive of liver failure, the BUN also increased to $60 \mathrm{mg} / \mathrm{dl}$ from $12 \mathrm{mg} /$ $\mathrm{ml}$ which is suggestive of kidney failure, similarly the creatinine levels also increased drastically. There was also severe gastrointestinal bleeding viz. hematemesis and melena. The case was promptly attended and rehydration of the body after the drug reaction was done with intravenous normal saline solution after complete stoppage of the anticancerous drug administration. The vomitions /Hematemesis and melena were effectively controlled with antiemetics and stryptics respectively. To boost up the immune system immunomodulant levamisole was given and liver was also stimulated with liver tonics for the effective metabolization of drugs. The values of blood biochemistry and hemograms started to come back to the normal levels by $7^{\text {th }}$ day of treatment. In the present study it was concluded that the combination therapy was successful as regards to reduction in the size of the tumour but its dose has to be either standardized or individual sensitivity has to be taken into consideration since only single case was attempted.

\section{Reference:}

[1]. Benjamine, M.M. (1985) Outline of Veterinary Clinical Pathology. IOWA state university press , printed in India by Kalyani publishers Ludhiana, New Delhi-110020

[2]. Booth, N.H. and McDonald, L.E. (1982), Jones Veterinary Pharmacology and Therapeutics. Fifth Edn. Kalyani publishers Ludhiana , New Delhi.

[3]. Brodey, R.S., Goldschmidt, M.A., Roszel, J.R., Canine mammary gland neoplasm. Journal of American Animal Hospital Association, 19: 61-90,1983.

[4]. Hammer, A.S., Couto, C.G., Filppi, J., Getzy, D., Shank, K., Efficasy and toxicity of VAC chemotherapy (Vincristine, Doxorubi cin and Cyclophosphamide) in dogs with hemangiosarcoma. J Vet Intern Med, May - Jun, 5 (3): 160-6, 1991.

[5]. Moulton, J. E., (1999) Tumors in Domestic Animals, $3^{\text {rd }}$ edition. Berkley, University of Califormia Press, pp. 518-543.

[6]. Sivakumar (2000) Clinicotherapeutic aspects of tumours in animals. (2000). MVSc. Thesis submitted to IVRI, Izatnagar.

[7]. Sorenmo, K.U., Jeglum, K.A., Helfand, S.C., Chemotherpy of canine hemangiosarcoma with doxorubicin and cyclophosphamide. J Vet Intern Med, 7(6): 370-376, 1993 